PNL-2665

UC-95d

\title{
Assessment of Powdered Activated Carbon Addition to Anaerobic Digesters at Salt Lake City, Utah
}

to

U.S. Department of Energy Urban Waste Technology Branch

Division of Building and Community Systems

Washington, D.C. 20545

by

S. B. Ahistrom

R. R. Spencer

April 1978

Pacific Northwest Laboratory

Richland, Washington 99352

Operated for the

U.S. Department of Energy

by 
NOTICE

This report was prepared as an account of work sponsored by the United States Government. Neither the United States nor the Depaiment of Energy, nor any of their employees, nor any of their contractors, subcontractors, or their employees, makes any wartanty, expreis or implied, or assumes any legat liability or responsibility for the accuracy, completeness or usefuiness of any information, apparatus, product or process disclosed, ct represents that its use would not inftinge privately owned rights.

The views, opinions and conclusions contaned in this teport are those of the contractor anc do not necessarily represent those of the L nited States Govermment or the United States Department ot Energy

\author{
PACIFIC NORTHWEST LABORATCRY \\ operated by \\ BATTELLE \\ for the \\ UNITED STATES DEPARTMENT OF ENERCY \\ Under Contract EY-75-C-05-7930
}

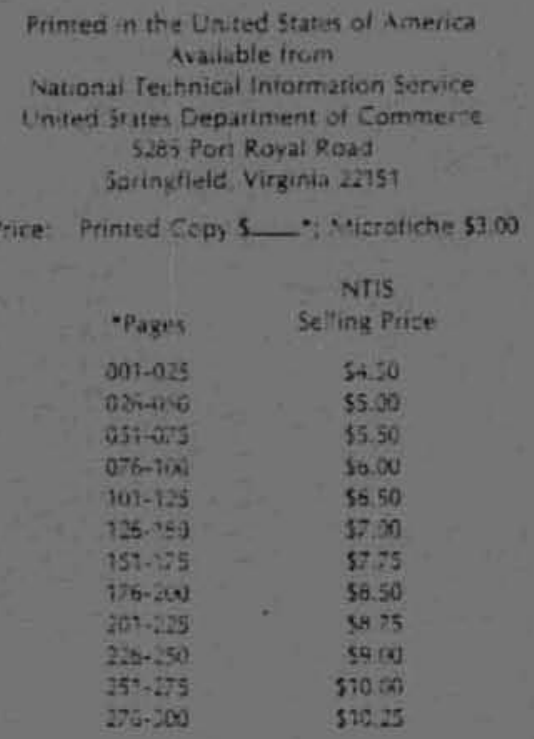




\section{5}

ASSESSMENT OF POWDERED ACTIVATED CARBON ADDITION TO ANAEROBIC DIGESTERS AT SALT LAKE CITY, UTAH

$E Y-76-C-06-1830$

to

U.S. Department of Energy Urban Waste Technology Branch Division of Building and Community Systems Washington, D.C. 20545

by

S. B. Ahlstrom

R. R. Spencer, Project Manager

Apri1 1978

Pacific Northwest Laboratory Richland, Washington 99352 operated for the Department of Energy

by Battelle Memorial Institute 


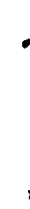




\section{SUMMARY}

The Salt Lake City Water Reclamation Plant has added powdered activated carbon to its influent wastewater since January 1977. Battelle Pacific Northwest Laboratory has gathered and analyzed operational data from the treatment plant in an effort to identify beneficial effects of the carbon. Benefits occurring during anaerobic digestion were of principal interest. Three potential areas of enhanced treatment were investigated:

1. Reduced solids in the primary clarifier effluent;

2. Increased anaerobic digester gas production; and

3. Increased sludge stabilization rate.

Review of the data from the Salt Lake City plant indicates that carbon did not significantly effect these aspects of the plant operation. However, the carbon dose rate was generaliy lower than that used in other carbon addition studies. Therefore, data from Salt Lake City can be interpreted to mean only that carbon does not produce the above benefits at low doses. Potential benefits identified by other investigators using higher carbon dose rates have not been invalidated. 

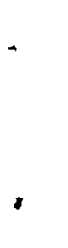
SUMMARY. ..................... $i$ i

LIST OF FIGURES. .................

LIST OF TABLES .............................. vii

ACKNOWLEDGMENTS. ........................ viii

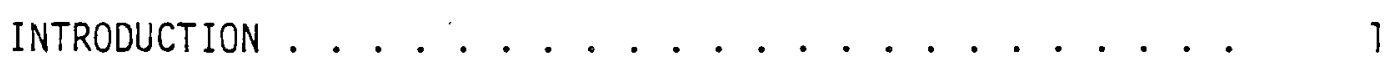

CONCLUSIONS. . . . . . . . . . . . . . . . 3

DESCRIPTION OF TREATMENT PLANT AND

CARBON ADDITION SYSTEM . .................... 5

DATA GATHERING AND REDUCTION . . . . . . . . . . . . . 9

DATA PRESENTATION AND DISCUSSION .............. 11 


\section{LIST OF FIGURES}

No.

Page

1 Salt Lake City Water Reclamation

Plant Layout. . . . . . . . . . . . . . . 6

2 TSS Values of Wastewater Treated at

the Salt Lake City Water Reclamation

Plant

3 Average Volume of Sludge Pumped to

Digesters at the Salt Lake City Water

Reclamation Plant

4 Average Total Gas Production at the

Salt Lake City Water Reclamation

Plant.

5 Average Anaerobic Digester Gas Production at the Salt Lake City Water

Reclamation Plant

6 Total Gas Produced Daily by Anaerobic Digesters at the Salt Lake City Water

Reclamation Plant.............

7 Daily Gas Production in Digester No.

1 -- Salt Lake City Water Reclamation

Plant

b Daily Gas Production in Digester No.

2 -- Salt Lake City Water Reclamation

Plant.

9 Daily Gas Production in Digester No.

3 -- Salt Lake City Water Reclamation

Plant.................. 20

10 Volatile Solids Destruction Accomplished

in Digester No. 1 at the Salt Lake City

Reclamation Plant

11 Volatile Solids Destruction Accomplished

in Digester No. 2 at the Salt Lake City

Reclamation Plant............... 22

12 Volatile Solids Destruction Accomplished

in Digester No. 3 at the Salt Lake City

Reclamation Plant 


\section{LIST OF TABLES}

No.

1 Properties of the Carbon Used at

the Salt Lake City Reclamation

Plant................... . 7

2 Events Pertinent to the Operation

of Anaerobic Digesters at Salt Lake

City, Utah.................. 7

3 Data Obtained from the Salt Lake City,

Utah Water Reclamation Plant. ........ 10 


\section{ACKNOWLEDGMENTS}

The authors wish to extend their gratitude to Jack Peterson, Willard DeVault, and Elgin Dyer of the Salt Lake City Water Reclamation Plant for their assistance in the collection of data necessary for the preparation of this report.

The secretarial and typing efforts of Nancy Painter are also gratefully acknowledged. 
.

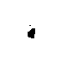


ASSESSMENT OF POWDERED ACTIVATED CARBON ADDITION TO

ANAEROBIC DIGESTERS AT SALT LAKE CITY, UTAH

\section{INTRODUCTION}

Since 1976 Battelle Pacific Northwest Laboratory (PNL) has investigated for the U.S. Department of Energy (DOE), the effect of powdered activated carbon on the anaerobic digestion of municipal sewage sludge. Part of this research program has involved a national survey of wastewater treatment plants in order to predict the impact of carbon addition on existing anaerobic digesters. On January 3, 1978, PNL contacted the Salt Lake City water Reclamation Plant and discovered that powdered activated carbon was being added to the wastewater treatment scheme in an effort to improve the digester operation as well as to enhance methane production. Most of the work at the Salt Lake City Plant was being sponsored by ARIES Consulting Corporation. At approximately the same time, a representative from ARIES contacted DOE and informed them of the carbon addition work at Salt Lake. Subsequently, DOE suggested to PNL that it would probably be worthwhile to learn more about this operation. This report presents Battelle's findings.

The major conclusions of the report are presented first. A description of the Salt Lake City plant and carbon addition system follows. The data gathering and reduction process is presented in the third section. The concluding section presents and discusses evidence relative to the claims that powdered activated carbon improves flocculation in the primary clarifier, enhances digester gas production, and yields a more stabilized sludge over the same digestion period. 
, 


\section{CONCLUSIONS}

- Studies at the Salt Lake City Water Reclamation Plant were conducted using an approximate carbon dose of $1 \mathrm{mg} / 1$ in the plant influent wastewater. This corresponds to a carbon concentration of about $350 \mathrm{mg} / 1$ of wet sludge in the anaerobic digesters. This dose is generally lower than that used by other investigators examining the addition of carbon to anaerobic digesters. Therefore, the results of the Salt Lake City research are applicable only to the low dose situation.

- Carbon addition failed to provide any definite measurable benefit as a flocculation agent in the primary clarifiers, as a means to enhance digester gas production, or as a catalyst in the sludge digestion and stabilization process.

- Any enhancement in the digestion system operation observed during the latter stages of the study period is probably attributabie to the cleaning of digester No. 2 . 
, - 


\section{DESCRIPTION OF TREATMENT PLANT AND CARBON ADDITION SYSTEM}

The Salt Lake City Water Reclamation Plant provides primary and secondary treatment to an average flow of $42 \mathrm{mgd}$. The plant treats mainly municipal sewage. The only large industries contributing to the plant flow are Coke and 7-Up bottling companies, Union Pacific Railroad (pretreats waste), Union $0 i 1$ Refinery (pretreats waste), and a very small chrome plating industry. The wastewater contains very few heavy metals, and only at low concentrations. As much as $22 \%$ of the plant flow is due to infiltration, mainly from sewer lines installed in the early 1900 's.

Figure 1 presents the general plant layout. The anaerobic digesters are arranged to operate as a two-stage system. However, the secondary digester is open and acts mainly as a holding tank.

The primary digesters are heated by external heat exchangers. Raw sludge and sludge from the digesters are combined in a make-up tank. This sludge mixture is passed through hot water/sludge heat exchangers and then discharged to the digesters.

Mechanical mixers are used in the primary digesters. The mixers are effective in localized areas but do a poor job of mixing the entire digester contents. According to plant personnel, the present mixing capacity is about $25 \%$ of that needed. The plant operations supervisor mentioned that digester No. 3 may be $2 / 3$ full of sand and grit. It also has a scum cap about $3 \mathrm{ft}$ deep. Digesters No. 1 and 2 have been cleaned recently. They probably have a scum cap that is 6-8 in. deep.

As indicated in Figure 1 , carbon is added to the plant influent just upstream of the primary clarifiers. Every two hours an operator adds a specified amount of carbon. Doses of $81 \mathrm{bs} / \mathrm{mgd}$ and $10 \mathrm{lbs} / \mathrm{mgd}$ have been used. Assuming that all of the carbon settles in the primary clarifiers, this is equal to a concentration of about $316-396 \mathrm{mg}$ of carbon per liter of wet sludge fed to the digesters. Other investigators seeking to determine if carbon benefits the digestion process have typically used doses of $1000-5000 \mathrm{mg} / 1$. A powdered activated carbon made from natural vegetable base materials (mainly redwood sawdust) was used at the Salt Lake City plant. This carbon may have been combined with lime and other chemicals prior to addition. The exact mixture added to the plant is not available. 


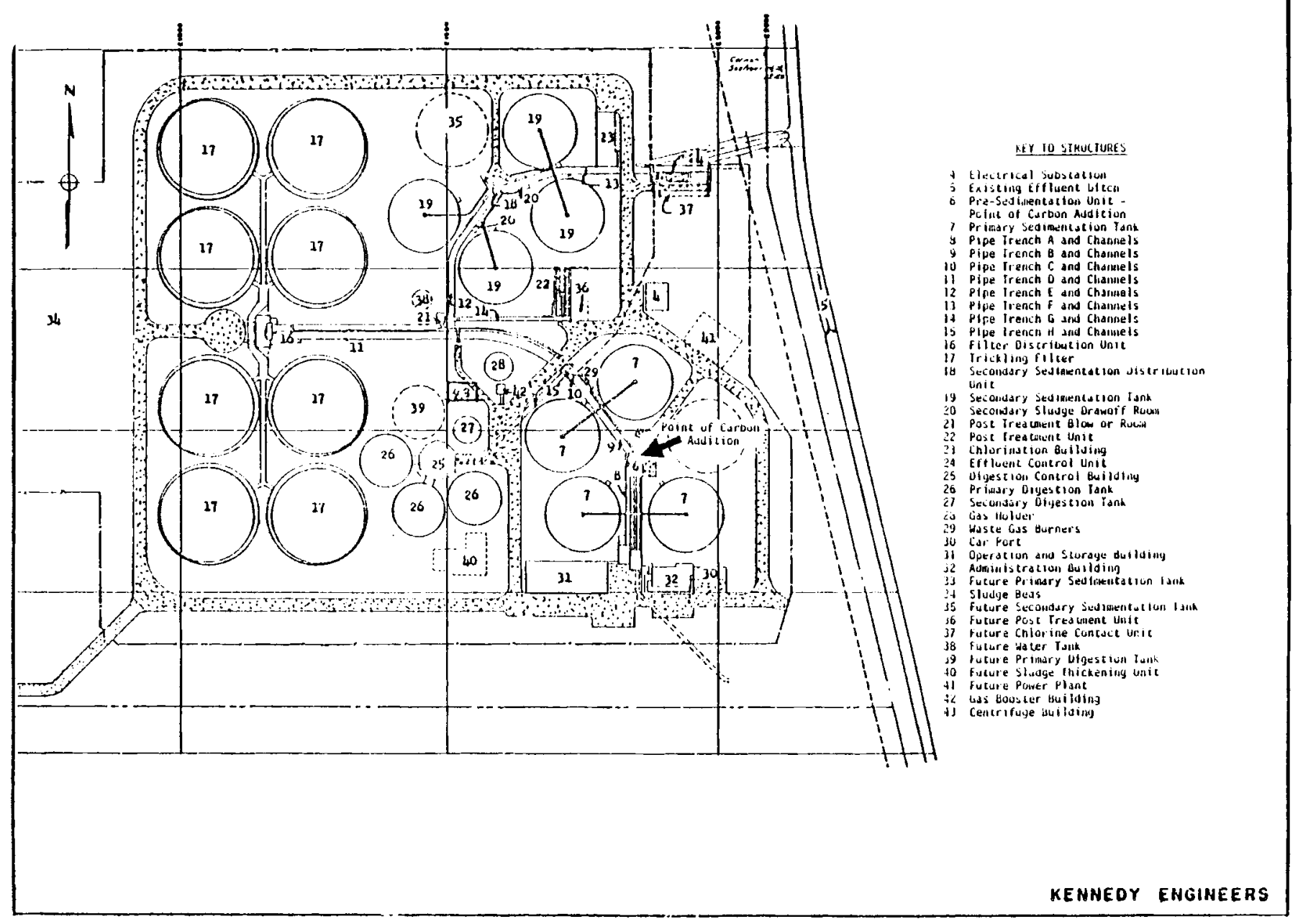

FIGURE 1. Salt Lake City Water Reclamation Plant Layout 
Properties of the carbon are given in Table 1. Table 2 shows activities at the treatment plant pertinent to the operation of the anaerobic digestion system.

TABLE 1. Properties of the Carbon Used at the Salt Lake City Water Reclamation Plant

$$
\text { Density: } 30 \pm 2 \mathrm{lbs} / \mathrm{ft}^{3}
$$

Maximum Moisture: 3 percent

Particle Size: Mesh Size \% Weight Passing Mesh

$\begin{array}{ll}100 & 97 \\ 200 & 85 \\ 325 & 65\end{array}$

TABLE 2. Events Pertinent to the Operation of Anaerobic Digesters at Salt Lake City, Utah

Date

September, 1965

May-Ju1y, 1975

November, 1976

January, 1977

JuTy-November, 1977

November, 1977

February 7, 1978
Event

Treatment plant began operation. Digester No. 1 taken off $l$ ine and cleaned. Added hydro-degritting unit at main pump station to replace the original aerated grit removal unit.

Began carbon addition; Dose $=8 \mathrm{lbs} / \mathrm{mgd}$.

Digester No. 2 taken off line and cleaned. No carbon was added during this period.

Started carbon addition again; Dose $=10 \mathrm{lbs} / \mathrm{mgd}$. Carbon addition stopped. 
.

$-$

, 


\section{DATA GATHERING AND REDUCTION}

Table 3 indicates the volume of data gathered by PNL from the Salt Lake City Water Reclamation Plant. The majority of this data was photocopied from the plant's daily operational records. One piece of data very important to the analysis of the digestion system, the amount of volatile solids in the feed sludge, was not available for a sufficient period of time to permit the comparison of conditions before and after carbon addition. Therefore, it was necessary to estimate this value.

The percent volatile solids and total solids in the feed sludge during the year 1977 were known. To estimate an average volume of volatile solids applied to the digesters from August 1975 to December 1976, the average percent volatile solids and percent total solids for 1977 were combined with the average volume of sludge pumped between August 1975 and December 1976. The formula used was:

Average lbs volatile solids applied to digester daily between August 1975 and December 1976

$$
=\left(\begin{array}{l}
\text { Average } \mathrm{ft}^{3} / \text { day sludge } \\
\text { feed to digesters } \\
\text { between August } 1975 \\
\text { and December } 1976
\end{array}\right) \times\left(62.5 \mathrm{lbs} / \mathrm{ft}^{3}\right) \times
$$

$$
\left(\begin{array}{l}
\text { Average } 1977 \text { percent } \\
\text { total solids }
\end{array}\right) \times\left(\begin{array}{l}
\text { Average } 1977 \text { percent } \\
\text { volatile solids }
\end{array}\right)
$$

where volatile solid's are expressed as a percentage of the total solids.

No attempt was made to estimate the volatile solids variation from month to month.

The remainder of the data evaluation process simply consisted of calculating monthly averages from daily values and combining monthly averages according to the following equations. When monthly averages were not available, the yearly average was used.

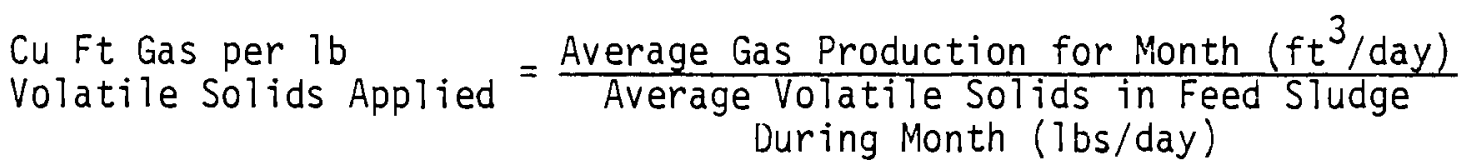

Percent Volatile Solids
Destruction

where: $V S_{F}=\frac{\text { lbs Volatile Solids in Feed }}{\text { Tbs Total Solids in Feed }}$ 


$$
V S_{D}=\frac{\text { lbs Volatile Solids in vigested Sludge }}{\text { lbs Total Solids in Digested Sludge }}
$$

TABLE 3. Data Obtained from the Salt Lake City, Utah Water Reclamation Plant

\begin{tabular}{|c|c|}
\hline Parameter & Period of Measurement \\
\hline Plant Flow & August 1975 to February 1978 \\
\hline Grit Removal & August 1975 to February 1978 \\
\hline Daily Chlorine Use & August 1975 to February 1978 \\
\hline Digester Temperature & August 1975 to February 1978 \\
\hline Gas Production by Digester & August 1975 to February 1978 \\
\hline $\begin{array}{l}\text { Volume of Sludge Pumped to } \\
\text { Digesters }\end{array}$ & August 1975 to February 1978 \\
\hline BOD & August 1975 to February 1978 \\
\hline TSS & August 1975 to February 1978 \\
\hline Settleable Solids & August 1975 to February 1978 \\
\hline $\begin{array}{l}\text { Digested Sludge: } \\
\text { Alkalinity } \\
\text { pH } \\
\text { Volatile Acids } \\
\text { Total Solids Concentration } \\
\text { Volatile Solids Concentration }\end{array}$ & $\begin{array}{lll}\text { January } 1976 \text { to February } 1978 \\
\text { January } & 1976 \text { to February } 1978 \\
\text { January } 1976 \text { to February } 1978 \\
\text { January } 1976 \text { to February } 1978 \\
\text { January } 1976 \text { to February } 1978\end{array}$ \\
\hline $\begin{array}{l}\text { Feed Sludge: } \\
\text { Total Solids Concentration } \\
\text { Volatile Solids Concentration }\end{array}$ & $\begin{array}{l}\text { January } 1977 \text { to February } 1978 \\
\text { January } 1977 \text { to February } 1978\end{array}$ \\
\hline
\end{tabular}




\section{OATA PRESENTATION AND DISCUSSION}

The data presented in this section are grouped into three categories, each of which investigates a potential benefit of carbon addition. Based on a preliminary analysis by ARIES Consulting Corporation and Salt Lake City Water Reclamation Plant personnel, each of these benefits was occurring at the Salt Lake City plant.

The first claim was that the carbon acted as a flocculent in the primary clarifier. It collected fines and made them more available to the biological community in the anaerobic digesters. If this was occurring one would expect to see a change in the concentration of total suspended solids (TSS) in the primary clarifier effluent as well as in the volume of sludge pumped to the digesters. Suspended solids inciude those particles that will settle to the bottom of a container under quiescent conditions as well as solids that are removable only by coagulation. Figure 2 presents the average monthly TSS values from August 1975 to February 1978. During the period of carbon addition (JanuaryJuly 1977 and November 1977-February 1978) the TSS concentration of the primary effluent remained very near those values recorded when no carbon was added. The fluctuations that did occur were erratic and more probably due to changes in the influent concentration, weather conditions, or plant operation than to the addition of carbon. Figure 3 shows the volume of sludge pumped to the digesters. Again, the volume during periods of carbon addition does not deviate outside the historical range of values.

The second claim was that gas production during digestion had increased by $80-90 \%$. The actual volume of gas produced during digestion is shown collectively in Figure 4 and by individual digester in Figure 5. When viewed over a period of 31 months, gas production during carbon addition fell within the range of values recorded when no carbon was added. As shown in Figure 5, the cleaning of digester No. 2 resulted in a notable improvement in gas production. For six months prior to cleaning but during carbon addition, digester No. 2 produced 50,000$70,000 \mathrm{cu} f t$ of gas per day. After cleaning but during carbon addition the production rate increased to values between 160,000 and 180,000 $\mathrm{ft}^{3} /$ day. The enhanced operation of digester No. 2 was responsible for the improved total gas production indicated in Figure 4 during the period November 1976 to February 1978. 


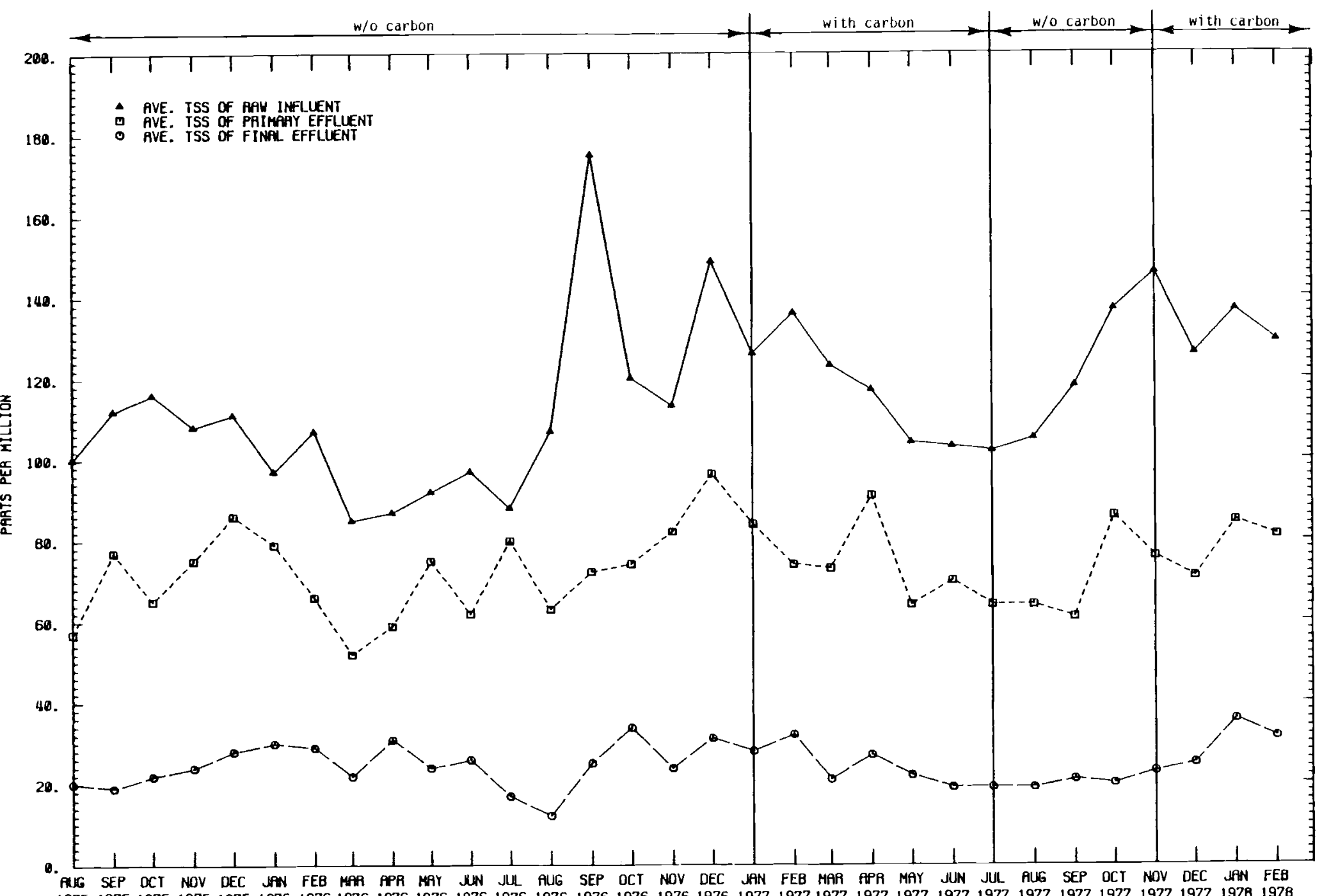

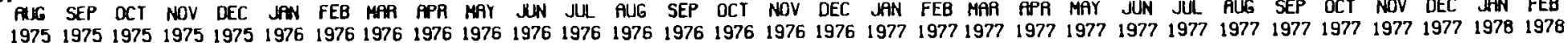

FIGURE 2. TSS Values of Wastewater Treated at the Salt Lake City Water Reclamation Plant 


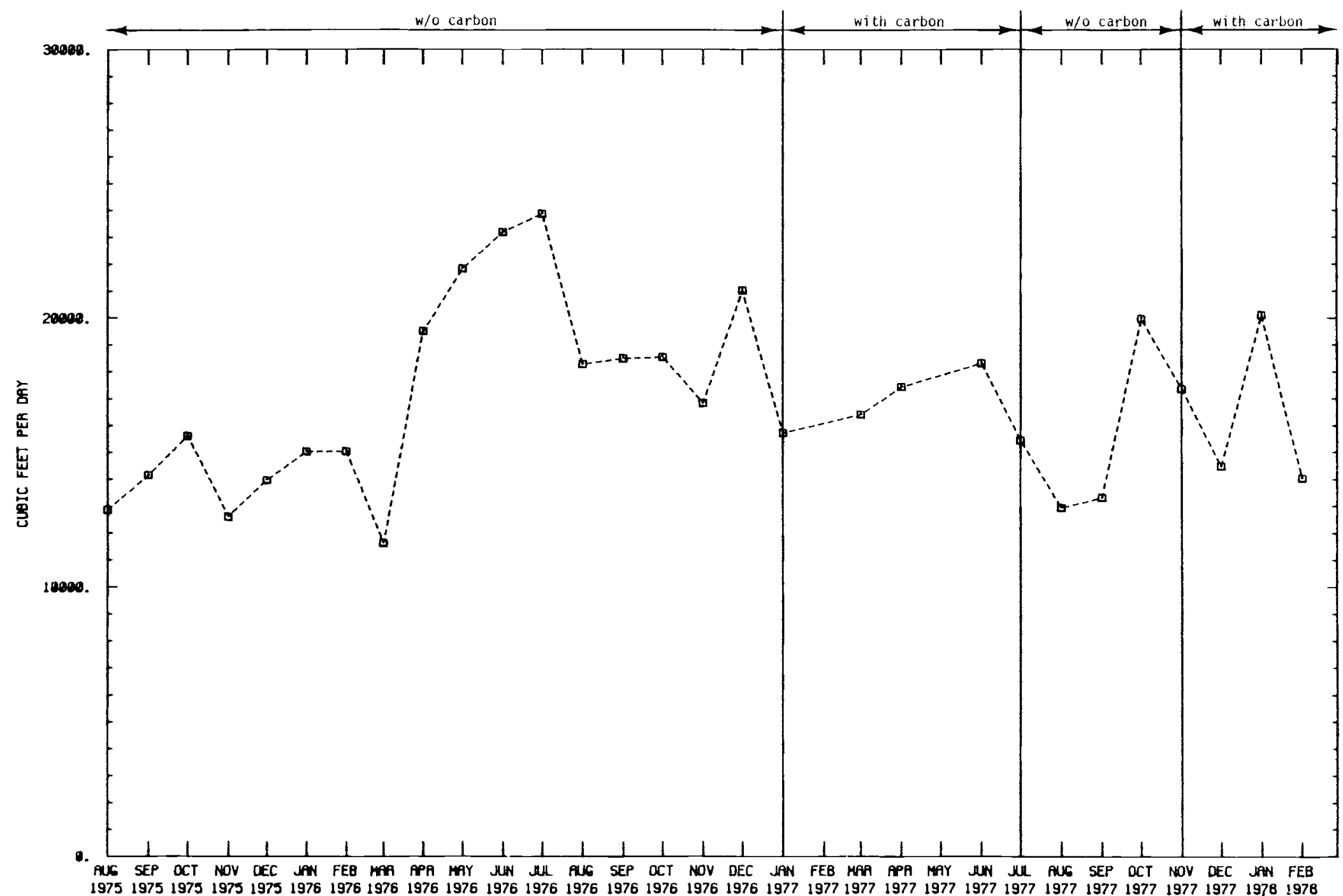

FIGURE 3. Average Volume of Sludge Pumped to Anaerobic Digesters at the Salt Lake City Water Reclamation Plant 


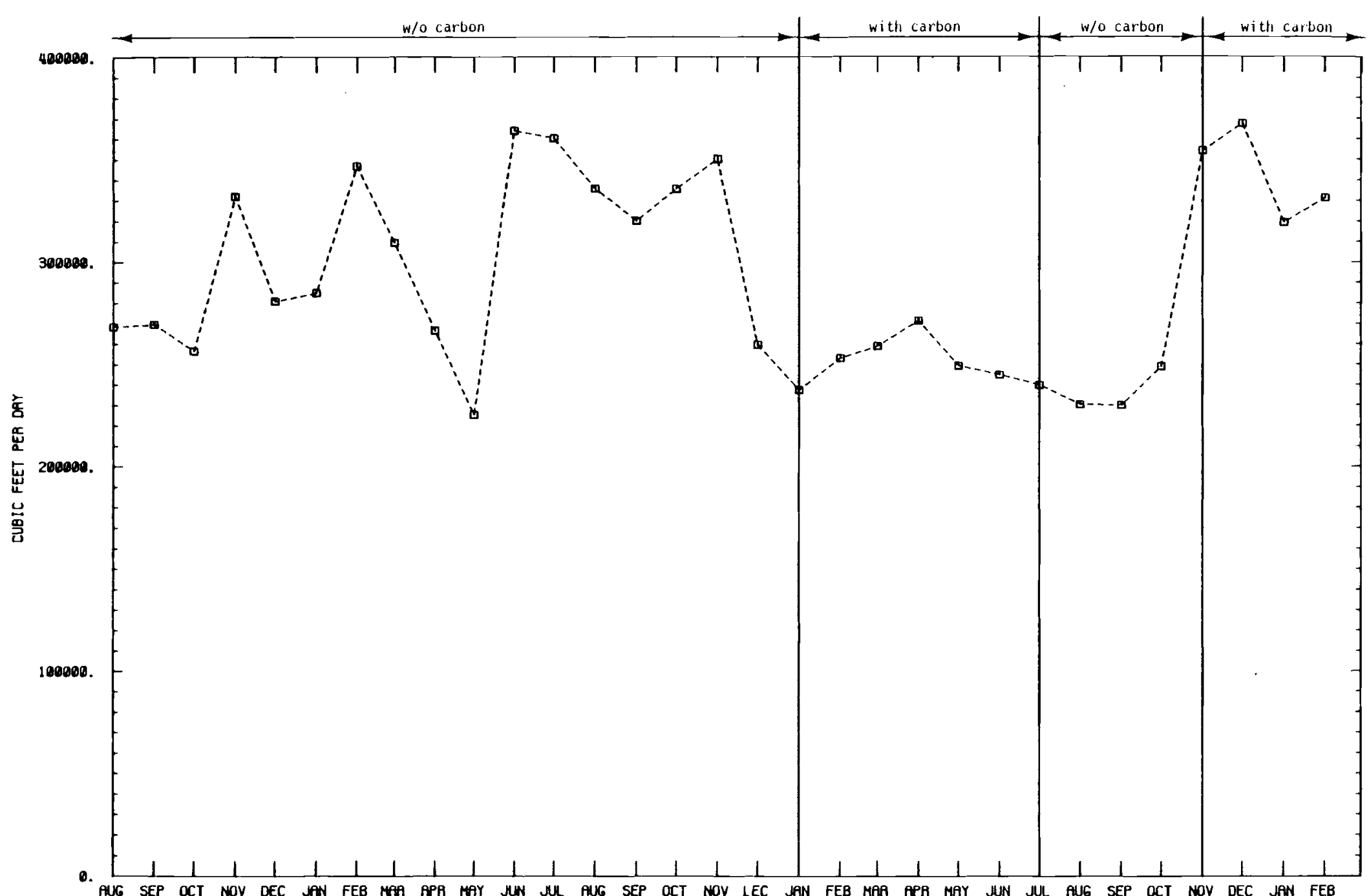

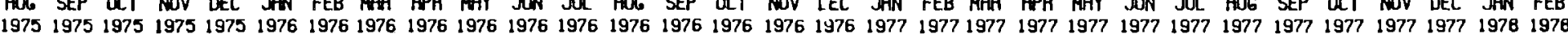

\section{FIGURE 4. Average Total Digester Gas Production at the} Salt Lake City Reclamation Plant 
$\vec{\sigma}$

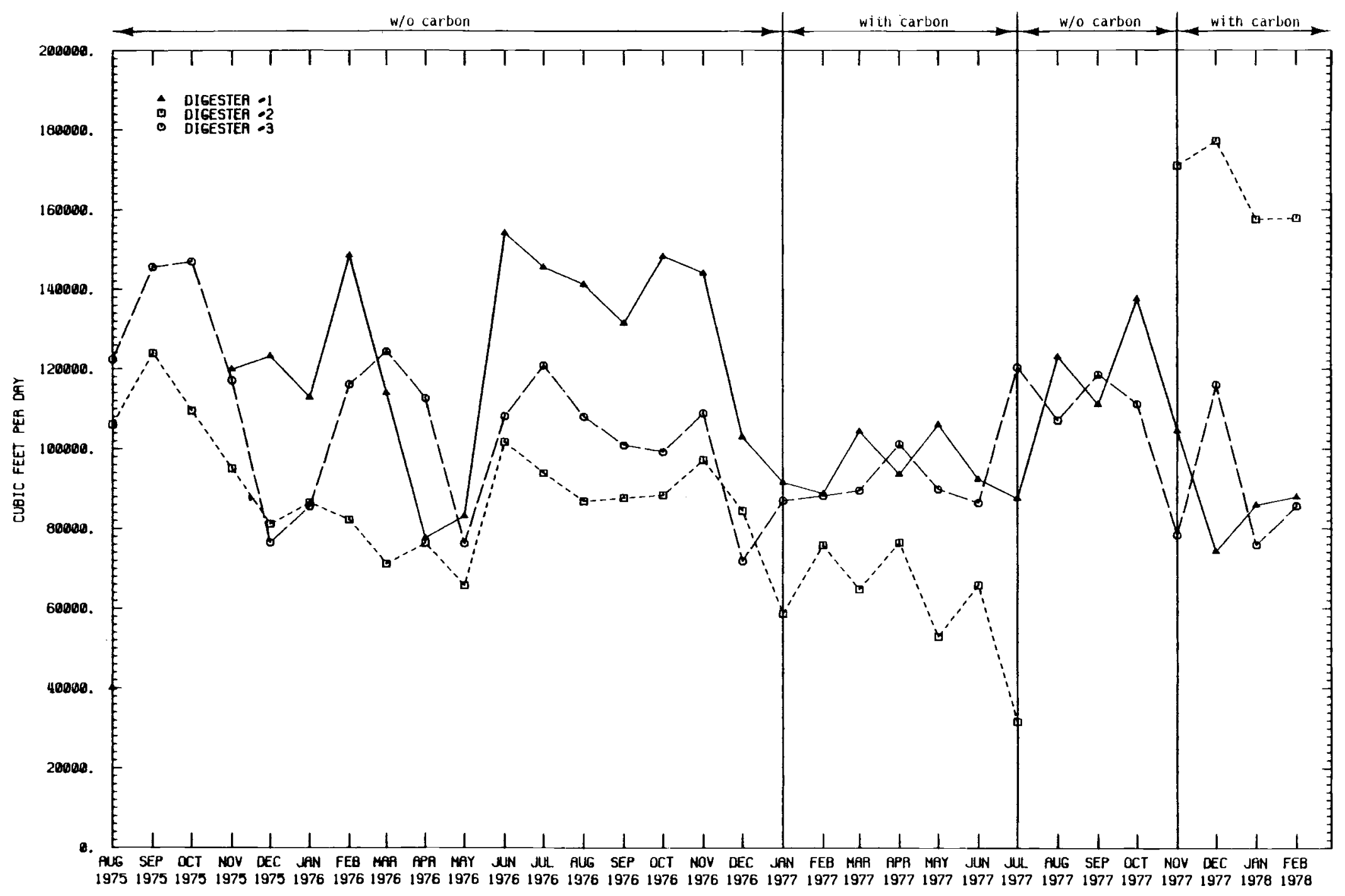

FIGURE 5. Average Anaerobic Digester Gas Production at the Salt Lake City Water Reclamation Plant 
Since gas production can fluctuate over a wide range, depending on the volatile solids content of the feed sludge, a more accurate comparison between gas production values can be made by taking into account the volume of volatile solids available to the biological community in the digester. Figures 6 through 9 represent the average volume of gas produced for each pound of volatile solids added to the digesters. Figure 6 indicates the gas production for all digesters; Figures 7 through 9 are for the individual digesters. Averages of the monthly gas production values over carbon-addition and no-carbon-addition periods are plotted on each graph. Typical values for municipal plants should range from 8 to $12 \mathrm{ft}^{3} / 1 \mathrm{~b}$ volatile solids added. However, excessive gas production rates sometimes occur during startup. As seen in Figure 8 , during startup of digester No. 2, which had been down for cleaning, an extremely high production rate was recorded. It is expected that this gas production rate will stabilize at a value nearer the $8-12 \mathrm{ft}^{3} / 1 \mathrm{~b}$ range. However, sufficient data to substantiate this expectation is not currently available.

Figures 6 through 9 lend very little substance to the claim concerning enhanced gas production. The increase in total gas production observed during the last four months in Figure 6 is due to improved operation of digester No. 2 during that startup period. It is unfortunate that more accurate data is not available for the control period (August 1975-December 1976). However, based on the estimated average value for the period, it appears that carbon addition has failed to significantly improve the gas production rate.

The third benefit claimed to have occurred at Salt Lake City's Water Reclamation Plant was that a more stabilized sludge could be obtained over the same period of time if carbon was added to the feed sludge. This claim is best investigated by studying the percent reduction in volatile solids during the digestion period. Figures 10 through 12 present the average, and when available the monthly percent volatile solids destruction for each digester. Results of a PNL survey of municipal anaerobic digesters indicated volatile solids destructions range from 32-70\%. An efficient digester typically operates at a value greater than $45 \%$. Except with the possible exclusion of digester No. 1 , 


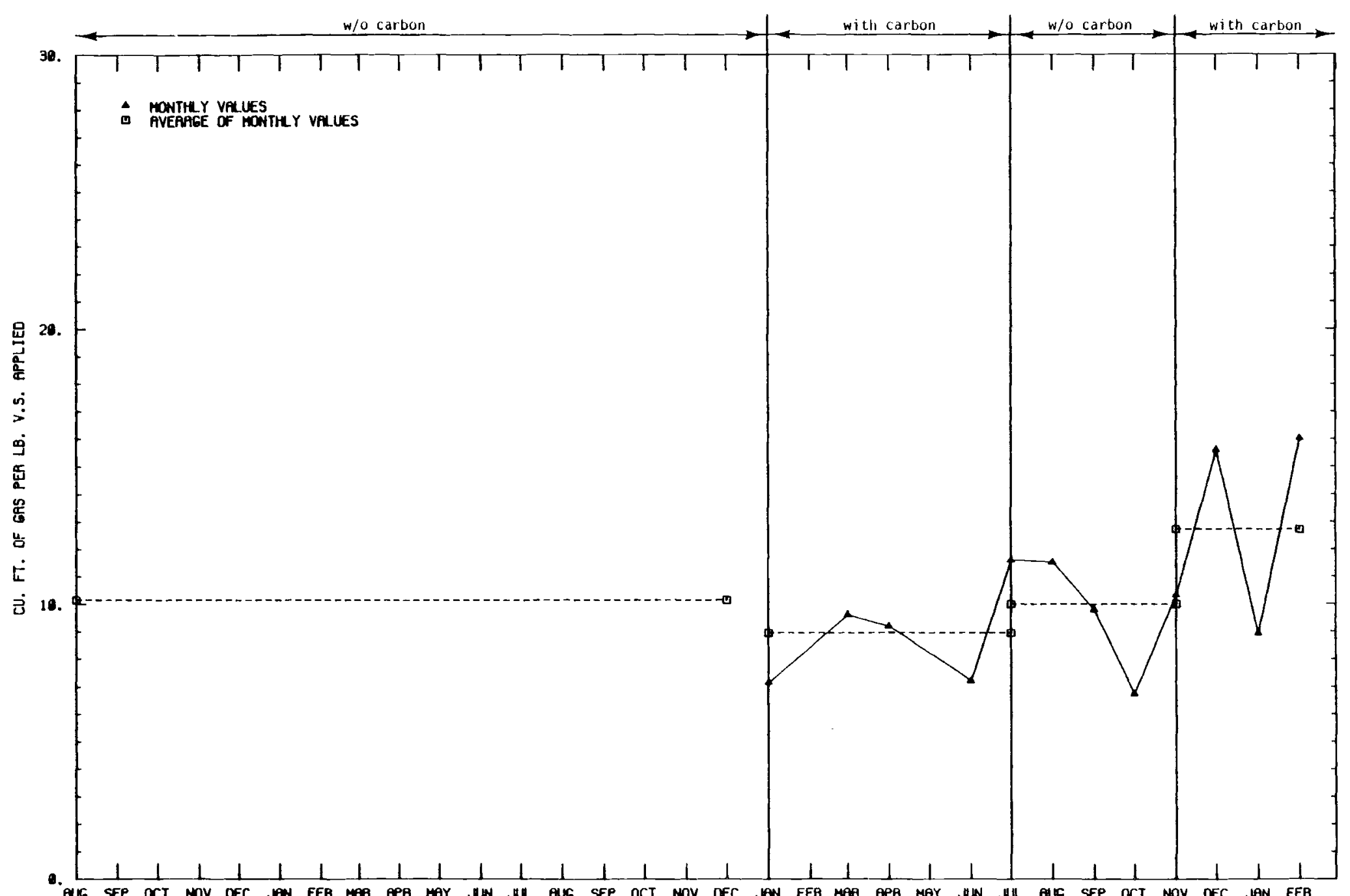

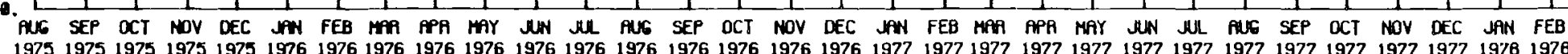

FIGURE 6. Total Gas Produced Daily by Anaerobic Digesters at the Salt Lake City Water Reclanation Plant 


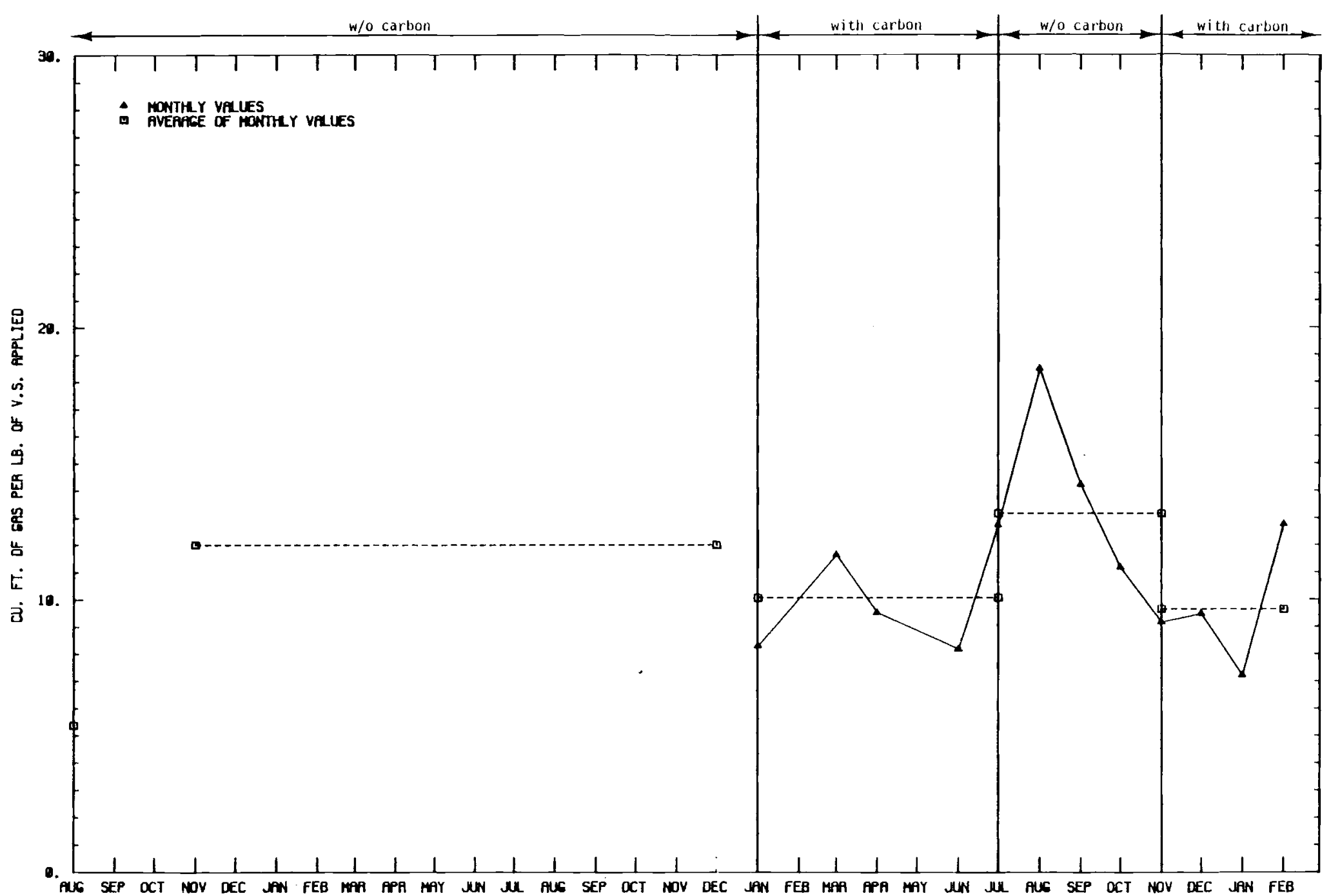

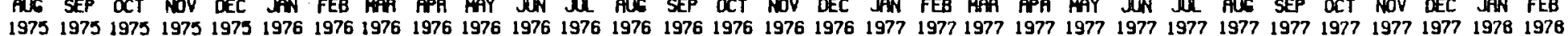

FIGURE 7. Daily Gas Production in Digester No. 1 -Salt Lake City Water Reclamation Plant 


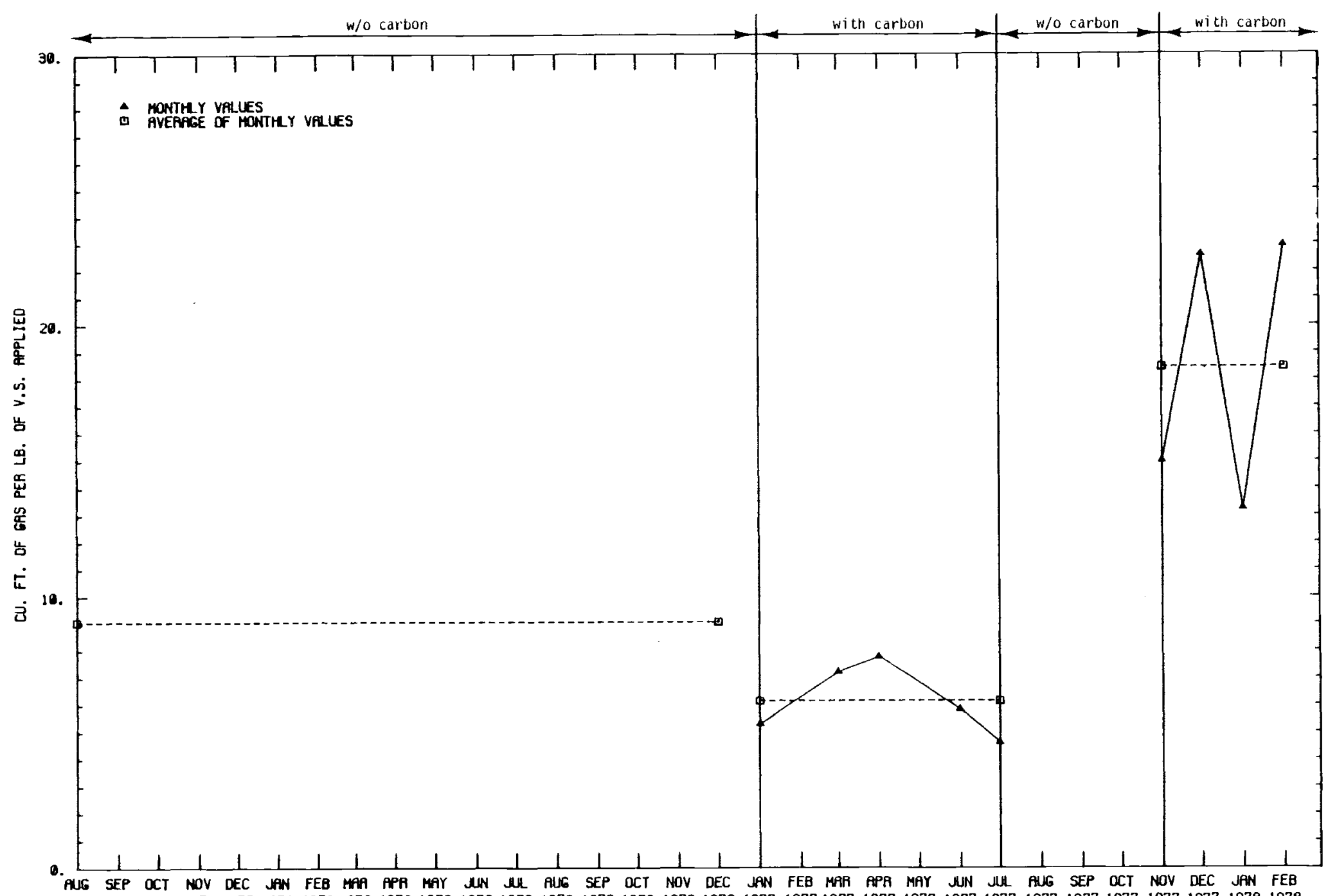

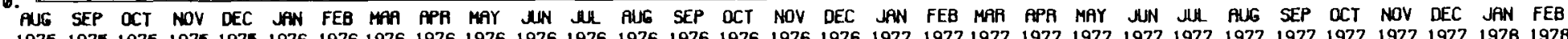
$197519751975197519751976197619761976197619761976197619761976197619761977 \quad 1977197719771977197719771977197719771977197719781978$

FIGURE 8. Daily Gas Production in Digester No. 2 -Salt Lake City Water Reclamation Plant 


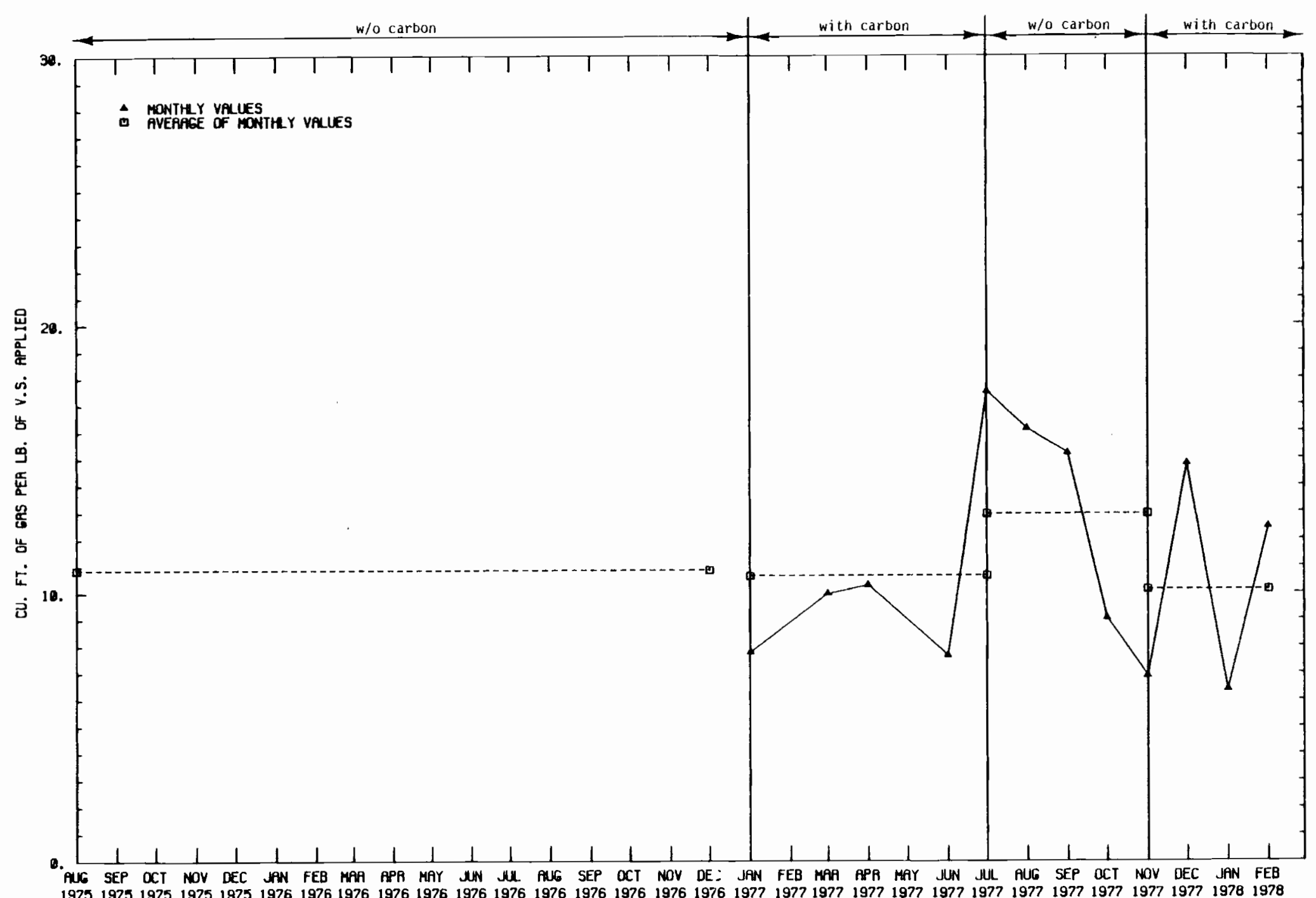

FIGURE 9. Daily Gas Production in Digester No. 3 -Salt Lake City Water Reclamation Plant 


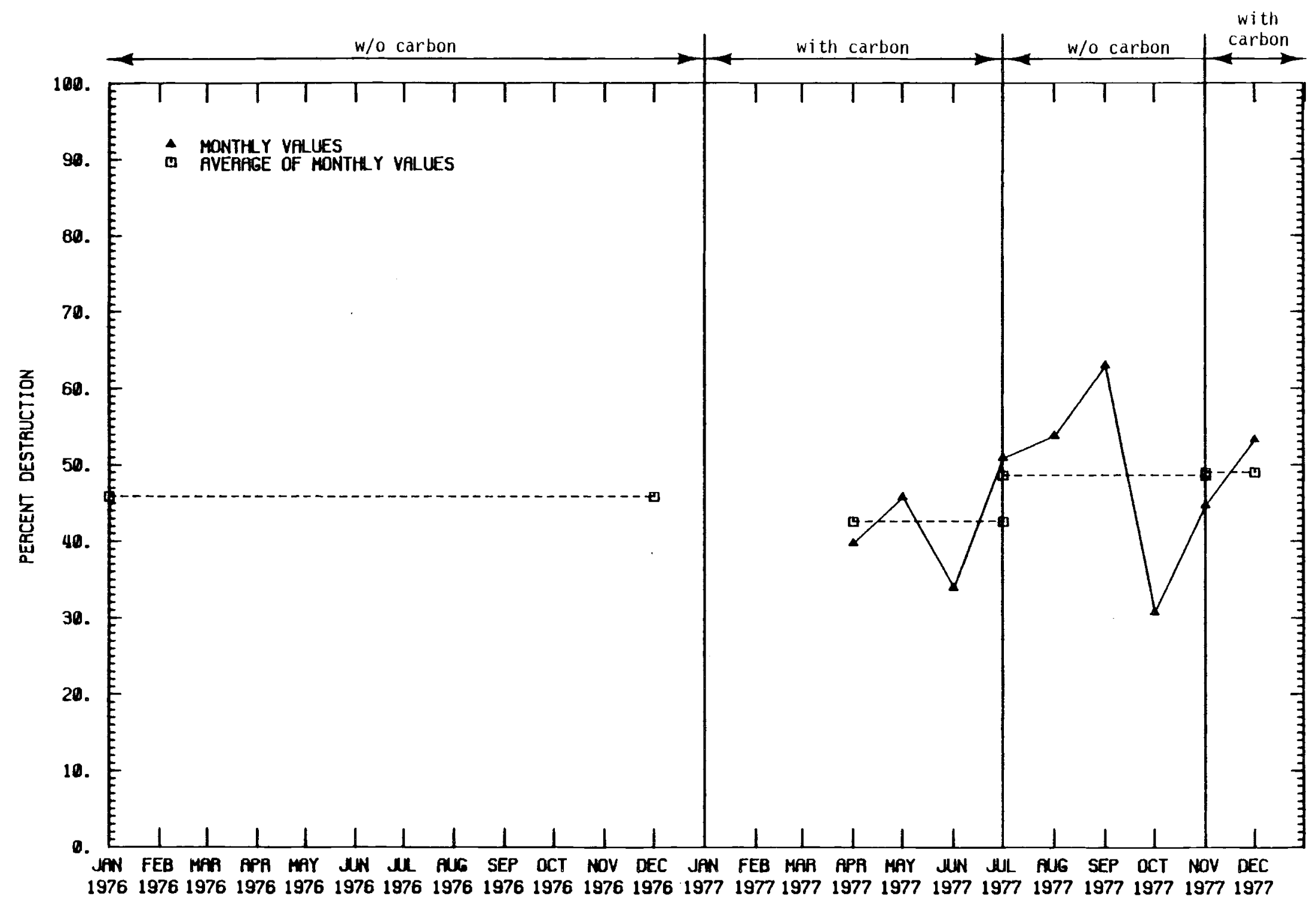

FIGURE 10. Volatile Solids Destruction Accomplished in Digester No. 1 at the Salt Lake City Water Reclamation Plant 


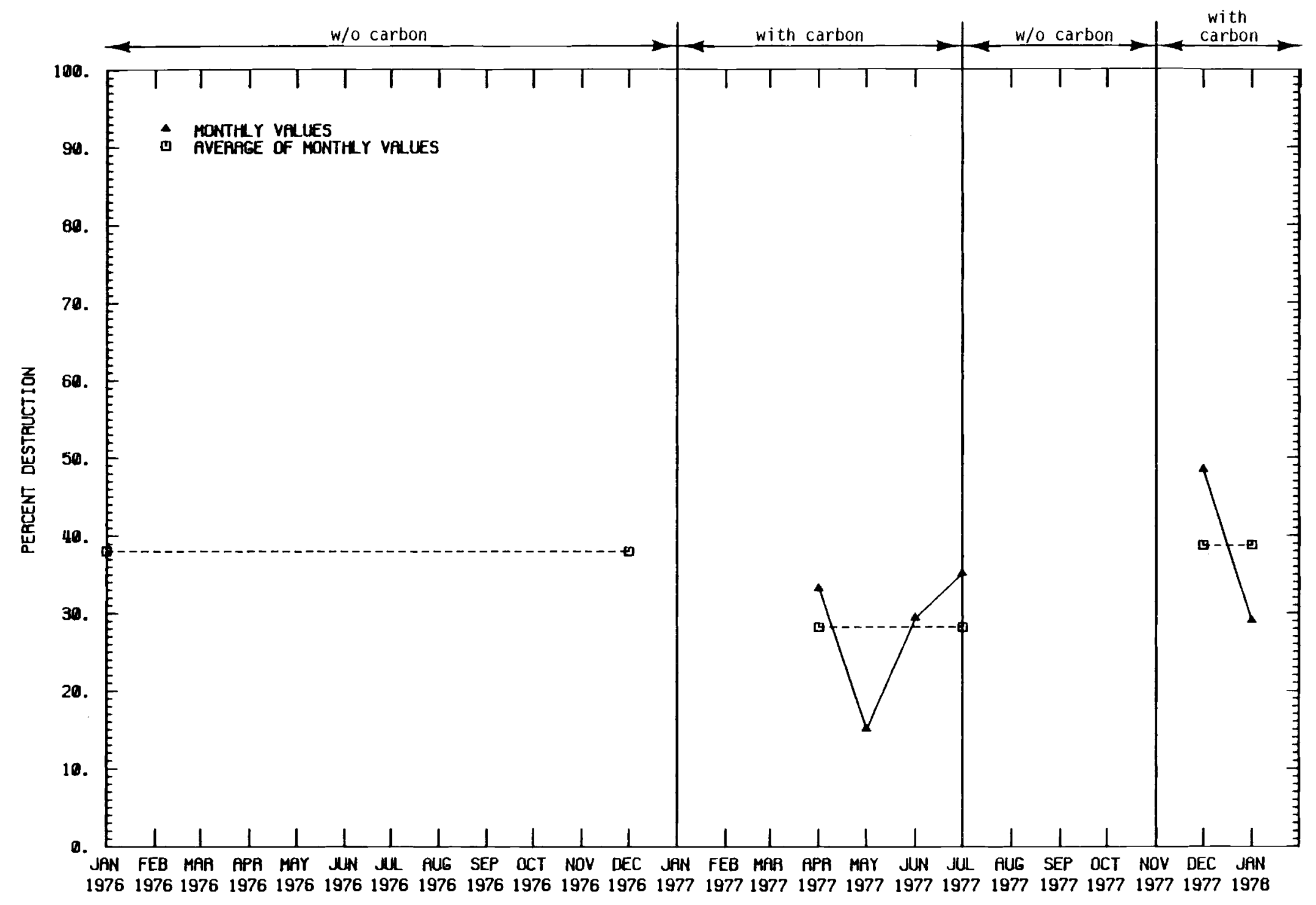

FIGURE 11. Volatile Solids Destruction Accomplished in Digester No. 2 at the Salt Lake City Water Reclamation Plant 


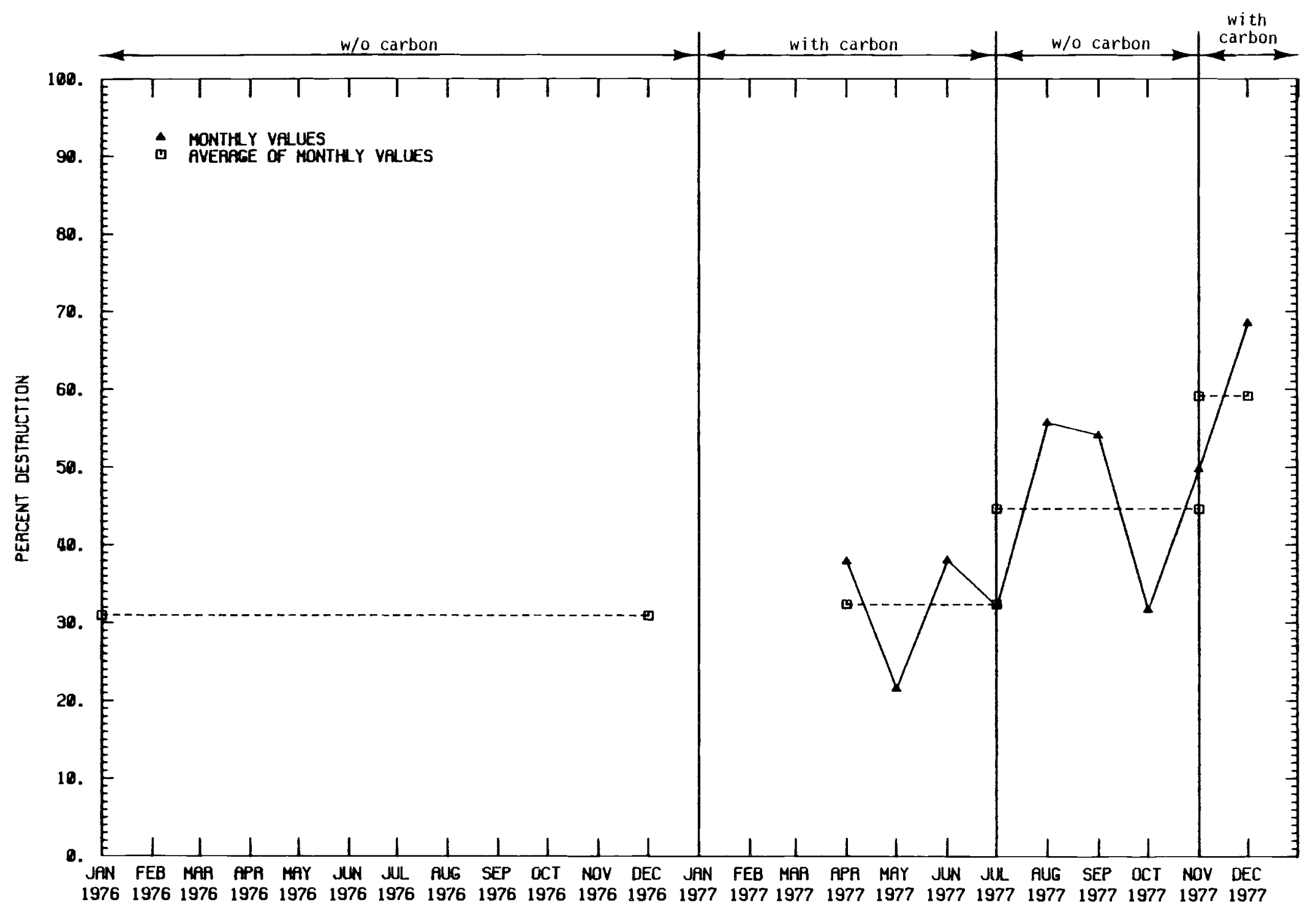

FIGURE 12. Volatile Solids Destruction Accomplished in Digester No. 3 at the Salt Lake City Water Reclamation Plant 
Salt Lake City has not consistently maintained this degree of solids destruction over the past 31 months. Carbon addition does not appear to have improved the degree of stabilization.

After digester No. 2 was cleaned, one would expect the average volatile solids destruction to be in the $45 \%$ and above range. Figure 11 indicates that such was not the case. This may be the result of a lack of data for the months November-December 1977 and January 1978. No monthly average for November was calculated since only one measurement was taken. Ten measurements were averaged to determine the December value. The average destruction in January was based on three daily mea surements.

Data collected at the Salt Lake City Water Reclamation Plant provide little substance to the three potential benefits of carbon identified above. However, it should be pointed out that the carbon dose was relatively low (about $300-400 \mathrm{mg} / 1$ ) and the digesters were generally unstressed, with volatile acids typically ranging 100-300 mg/1. Alternatively, experiments at PNL have not evaluated carbon doses of less than $1500 \mathrm{mg} / 1$ in unstressed systems. At this nigher dose, increases in gas production of $5-20 \%$ and corresponding improvements in volatile solids destruction have been observed. In stressed digesters, gas productions were enhanced by as much as $30 \%$ with a $500 \mathrm{mg} / 1$ carbon dose. In summary, none of the experimental studies conducted at PNL accurately simulate test conditions at the full-scale facility. The most that can be said is that PNL research does not refute the findings at Salt Lake City. 


\section{DISTRIBUTION}

No. of

Copies

OFFSITE

A. A. Churm

Chicago Patent Group

Department of Energy

9800 South Cass Avenue

Argonne, IL 60439

27 DOE Technical Information Center

5 D. K. Walter

Department of Energy

20 Massachusetts Avenue

Washington, DC 20001

1 M. Bender

Argonne National Laboratory

9700 South Cass Avenue

Argonne, IL 60439

$1 \mathrm{~J}$. Farrel

Environmental Protection Agency Water Quality Office

Robert A. Taft Research Center

4676 Columbia Parkway

Cincinnati, OH 45226

1 B. V. Salotto

Environmental Protection Agency

Municipal and Environmental

Research Laboratory

Cincinnati, $\mathrm{OH} 45268$

1 R. E. Speece

Betz Chair Professor of

Environmental Engineering

Drexel University

Philadelphia, PA 19104

1 A. J. Shuckrow

Touhill, Shuckrow and Associates, Inc.

P. 0. Box 11022

Pittsburgh, PA 15237
No. of

Copies

1 W. E. Devault

Operations Supervisor - Water

Reclamation Plant

1850 North Redwood Road

Salt Lake City, UT 84116

1 J.Peterson

Superintendent - Water Reclamation Plant

1850 North Redwood Road

Salt Lake City, UT 84116

ONSITE

2 DOE RL

H. E. Ranson

G. L. Liffick

24 Battelle-Northwest

B. W. Mercer

S. B. Ahlstrom (4)

R. R. Spencer (10)

J. A. Coates

G. W. Dawson

D. B. Cearlock

Technical Information (5)

Technical Publications 
Ho. of

Copies

OFFSITE

14

United States Nuclear Regulatory Commission
P. S. Check
F. D. Coffman
D. Houston
U. V. Johnston
R. Lobe 1
G. Marino
R. 0. Meyer
M. L. Picklesimer
D. Powers
L. S. Rubenstein
D. F. Ross, Jr.
H. H. Scott
M. Tokar
J. Voglewede

$4 \quad$ Electric Power Research Institute

F. E. Gelhaus

H. Ocken

S. T. 01dberg

J.T.A.Roberts

3

AECL/Chalk River ilational Labs

A. S. Bain

J. C. Wood
C. R. Hann (5)

Technical Information Files (5)

Technical Publications

H. J. Bailey

J. O. Barner

E. R. Bradley

J. A. Christensen

E. L. Courtright

M. E. Cunningham

M. D. Freshiey

R. L. Goodman

P. L. Hendrick

D. D. Lanning
R. K. Marshall

R. P. liärshal1

C. L. Mohr

F. E. Panisko

P. J. Pankaskie

R. E. Schreiber

S. R. Wagoner

G. D. White

R. E. Williford

C. L. Wilson 
